TITLE:

\title{
A New Species of Marine Tardigrada of the Genus Florarctus (Heterotardigrada, Halechiniscidae) from Japan
}

\author{
$\operatorname{AUTHOR(S):~}$
}

Noda, Hirokuni

\section{CITATION:}

Noda, Hirokuni. A New Species of Marine Tardigrada of the Genus Florarctus

(Heterotardigrada, Halechiniscidae) from Japan. PUBLICATIONS OF THE SETO MARINE BIOLOGICAL LABORATORY 1987, 32(4-6): 323-328

\section{ISSUE DATE:}

1987-12-26

URL:

http://hdl.handle.net/2433/176140

RIGHT: 


\title{
A New Species of Marine Tardigrada of the Genus Florarctus (Heterotardigrada, Halechiniscidae) from Japan
}

\author{
By \\ Hirokuni Noda \\ Seto Marine Biological Laboratory, Kyoto University, Shirahama, \\ Wakayama, 649-22, Japan
}

With Text-figure 1 and Table 1

The present paper deals with a new species of marine Tardigrada of the genus Florarctus Delamare Deboutteville \& Renaud-Mornant, 1965, from Tanabe Bay on the Pacific coast of Japan. This is the first record of the genus Florarctus from Japan.

Sediment samples were collected from a gravel bottom of $10 \mathrm{~m}$ depth off To-shima Rock, near the Seto Marine Biological Laboratory $\left(33^{\circ} 41^{\prime} 30^{\prime \prime} \mathrm{N} ; 135^{\circ} 20^{\prime} 30^{\prime \prime} \mathrm{E}\right)$. Animals were extracted by decanting through a $40 \mu \mathrm{m}$ mesh sieve with fresh water, and then fixed in 4-5 percent formalin buffered with Borax. Each specimen was mounted onto a slide with anhydrous glycerin. The number appending to each specimen is the author's reference number. All the specimens that are used for the present work will be deposited in the Seto Marine Biological Laboratory. The terminology follows Kristensen (1984).

\section{Florarctus glareolus sp. nov.}

Type series. Seven specimens from To-shima Rock: holotype (0113; 25, May, 1984) a female; paratypes 2 females $(0044 ; 0075), 1$ male $(0114)$, and 2 specimens of undetermined sex $(0110 ; 0112)$ (25, May, 1984) and 1 male (0042) (11, July, 1984).

H ol o t y pe: Mature female with indistinct gonopore (Fig. 1A). Body, exclusive of aliform expansion, $153.5 \mu \mathrm{m}$ long, $88.6 \mu \mathrm{m}$ wide at the height of leg III, flattened dorsoventrally, consisting of head, of which frontal edge is nearly straight, and nearly oval trunk. Dorsal cuticle with several, faint, transverse creases. Ventral cuticle smooth. Body ornamental aliform expansions frontal, anterolateral, posterolateral and caudal. The frontal expansion with a weak central notch, fused with the proximal half of the scapus of the internal cirrus near the lateral end of the expansion. The anterolateral expansion bilobed; its anterior lobe without a central notch; its posterior one with a weak notch. The posterolateral expansion with a distinct, round, central notch. The caudal one four-lobed with a distinct, round, central notch and a pair of side notches. All the aliform expansions but frontal one with procuticular supports. Very fine punctulation present on each aliform expansion.

Publ. Seto Mar. Biol. Lab., 32 (4/6), 323-328, $1987 . \quad$ (Article 11) 


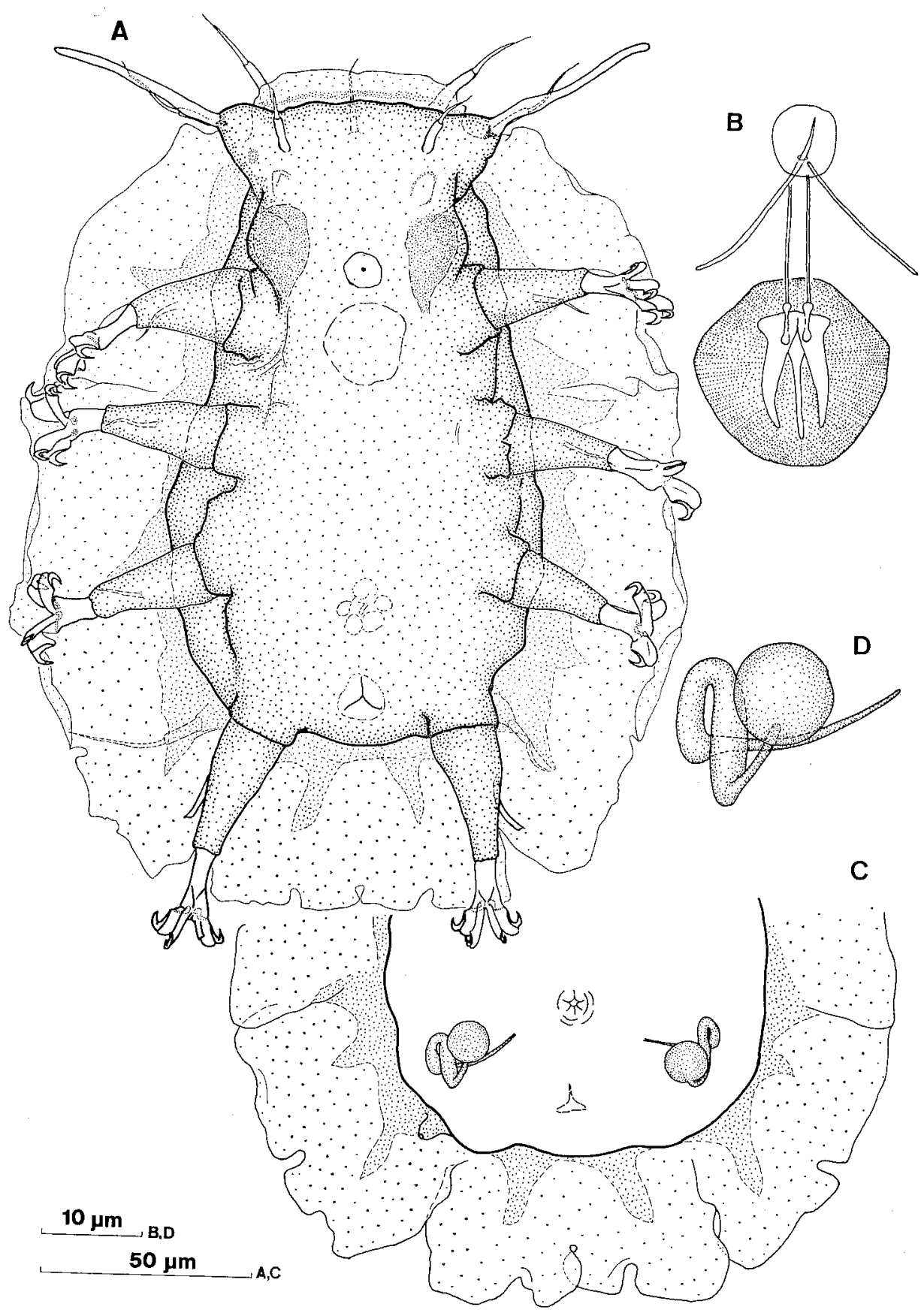

Fig. 1. Florarctus glareolus sp. nov. from Tanabe Bay, Japan. Holotypic female (A) and a paratypic female (B-D). A. Ventral view; B. Ventral view of buccal apparatus; C. Dorsal view of posterior part of trunk; D. Dorsal view of seminal receptacle. 
Cephalic and somatic appendages as follows. Median cirrus $18.2 \mu \mathrm{m}$, situated middorsally at a point $8 \mu \mathrm{m}$ posterior to the anterior margin of the head exclusive of the frontal aliform expansion, consisting of a flagellum $(14.6 \mu \mathrm{m})$ and a short distal hair $(3.6 \mu \mathrm{m})$. A pair of internal cirri $31.6 \mu \mathrm{m}$, each arising from the anterior margin of the head, $21 \mu \mathrm{m}$ apart from the mesial point of the anterior edge of the head, consisting of a thick scapus $(15 \mu \mathrm{m})$, a tapered flagellum $(12.3 \mu \mathrm{m})$ and a distal hair $(4.3 \mu \mathrm{m})$. A pair of external cirri $22.8 \mu \mathrm{m}$, each situated ventrally at a point $6 \mu \mathrm{m}$ posterior to the internal cirri, more mesially than the internal cirri, consisting of a scapus $(10.3 \mu \mathrm{m})$, a flagellum $(10 \mu \mathrm{m})$ and a distal hair $(2.5 \mu \mathrm{m})$. A pair of lateral cirri $28.2 \mu \mathrm{m}$, each situated on the apex of the lateral projection of the head, consisting of a scapus $(10.6 \mu \mathrm{m})$, a flagellum $(14.1 \mu \mathrm{m})$ and a distal hair $(3.5$ $\mu \mathrm{m})$; the scapus fused with the proximal part of the primary clava. A pair of primary clavae $43.3 \mu \mathrm{m}$ long, ventrally adjacent to the lateral cirri, thickest at a 14 percent point of its length, slightly tapered, with round tip, each with van der Land's body at its insertion. Secondary clava was not detected but possibly present as in other Florarctus species. A pair of somatic cirri $\mathrm{E} 39.7 \mu \mathrm{m}$, each situated dorsally on a weak projection of similar appearance as a procuticular support of the aliform expansion, consisting of a scapus $(11.2 \mu \mathrm{m})$, a flagellum $(25 \mu \mathrm{m})$ and a distal hair (3.5 $\mu \mathrm{m})$, with a distinct pedestal (=cirrophore).

With four pairs of legs. Legs situated at a 32 percent point (leg I), a 53 percent point (II), a 70 percent point (III) and a 95 percent point (IV) of body length. Each leg consisting of coxa, femur, tibia and tarsus. The tibia and the tarsus retractile inside the femur. A spine present on the median part of the outer side

Table 1. Measurements of the type specimens of Florarctus glareolus sp. nov. collected from Tanabe Bay, Japan. BL: body length; BW: body width; CE: cirrus E; EC: external cirrus; F : female; IC: internal cirrus; LC: lateral cirrus; M: male; MG: median cirrus; PIV: papilla of leg IV; PG: length of primary clava; SI: spine of leg I; SII: spine of leg II; SIII: spine of leg III. All measurements in $\mu \mathrm{m}$.

\begin{tabular}{lrrrrrrr}
\hline No. & 0042 & 0044 & 0075 & 0110 & 0112 & 0113 & 0114 \\
\hline Sex & M & \multicolumn{1}{c}{ F } & \multicolumn{1}{c}{ F } & \multicolumn{1}{c}{ ? } & ? & F & M \\
BL & 123.1 & 205.0 & 158.0 & 153.9 & 110.4 & 153.5 & 150.9 \\
BW & 63.1 & 105.1 & 93.0 & 99.8 & 68.3 & 88.6 & 89.3 \\
MG & 22.1 & 27.0 & 19.5 & 19.6 & 16.0 & 18.2 & 24.1 \\
IC & 29.6 & 41.8 & 18.2 & 30.5 & 21.6 & 31.6 & 31.5 \\
EG & 21.3 & 31.7 & 13.5 & 24.6 & 15.0 & 22.8 & 23.9 \\
LG & 28.8 & 43.9 & 17.6 & 27.7 & 23.8 & 28.2 & 35.4 \\
PG & 60.4 & 63.5 & 25.6 & 45.3 & 30.6 & 43.3 & 43.0 \\
CE & 39.5 & 49.0 & 33.4 & 40.4 & 30.5 & 39.7 & 29.6 \\
S I & 12.0 & 21.0 & 5.3 & 15.0 & 7.5 & 13.5 & 13.6 \\
S II & 11.3 & 20.3 & 6.3 & 15.5 & 6.8 & 14.3 & 15.0 \\
S III & 11.3 & 20.3 & 7.5 & 14.6 & 10.9 & 12.4 & 12.4 \\
PIV & 11.3 & 20.3 & 6.0 & 13.1 & 9.0 & 12.8 & 12.8 \\
\hline
\end{tabular}


of each femur of legs I-III. Each spine consisting of only a flagellum, $13.5 \mu \mathrm{m}$ on leg I, $14.3 \mu \mathrm{m}$ on leg II and $12.4 \mu \mathrm{m}$ on leg III. A papilla present on the median part of the outer side of the femur of leg IV, slightly curved, $12.8 \mu \mathrm{m}$ in length, equal in diameter along its length, ending abruptly; a distinct pedestal at its base absent; van der Land's body present at the insertion of the papilla. Each tarsus bearing four digits. External digit very short, about half as long as internal digit, with hook-shaped peduncle at its base. External claw consisting of a small distal piece and a large proximal piece with distinct calcar externum, with neither secondary hook nor accessory one, retractile inside the claw sheath. Internal claw smaller than external claw, consisting of a single piece, not segmented as external claw, with an accessory hook, with an indistinct calcar externum, retractile inside the claw sheath.

Eye pigment spots absent.

Several internal structures of the trunk could not be observed of the holotypic female. The following additional description on a paratypic female would be available for them.

Paratypic female (0075): Mouth opening on mouth cone situated ventrally and $37.5 \mu \mathrm{m}$ posteriorly to the anterior margin of the head. Stylet $19.5 \mu \mathrm{m}$ in length, thin and simple with neither branches nor excrescences. Anterior tip of right stylet exposed out of mouth. Buccal tube $15.0 \mu \mathrm{m}$ long, $2.3 \mu \mathrm{m}$ in diameter. Placoids very thick, consisting of ventral excrescences at the posterior end of buccal tube, thick beak-shaped lateral placoids, and a central placoid which is thinner than the lateral ones. Pharyngeal bulb (Fig. 1B) about $19.5 \mu \mathrm{m}$ in diameter, situated at a 40 percent point of body length. Anus (Fig. 1G) of the same appearance as is known in other Florarctus species, ventrally situated at a point $13 \mu \mathrm{m}$ anterior to the posterior margin of the trunk.

Gonopore of six lobed type, situated at a point $25 \mu \mathrm{m}$ anterior to the anus. Seminal receptacle (Fig. 1D) present at the height between the gonopore and the anus; the vesicle spherical, $6.8 \mu \mathrm{m}$ in diameter. The genital duct starting from posteroventral face of the vesicle; the first $8 \mu \mathrm{m}$ of the duct thin, extending posteriorly, and turning anteriorly to the second part; the second part $20 \mu \mathrm{m}$ long and thick, $3.8 \mu \mathrm{m}$ in diameter, J-shaped, at first extending anteriorly, and next turning posteriorly; the last part thin, $20 \mu \mathrm{m}$ in length, nearly straight to the genital opening. Genital opening situated ventrally on a point at a distance of $15 \mu \mathrm{m}$ from the gonopore, with no distinct genital papilla.

Remarks. Five species have been known in the genus Florarctus as follows: $F$. heimi Delamare Deboutteville \& Renaud-Mornant, 1965, F. salvati Delamare Deboutteville \& Renaud-Mornant, 1965, F. antillensis van der Land, 1968, F. cinctus RenaudMornant, 1976, and F. hulingsi Renaud-Mornant, 1976.

$F$. glareolus sp. nov. accords with $F$. cinctus in the combination of the following character states: body is fringed with flower-like aliform expansions; all the aliform expansions except the frontal one bear distinct procuticular supports; the anterolateral and the midlateral aliform expansion fused each other; the midlateral and 
posterolateral aliform expansions fused with each other only partially. However, the new species is easily discernible from $F$. cinctus in a structure of the dorsal cuticle, because the new species have not mammilliform sculptures as in $F$. cinctus.

Although the dorsal cuticle and the four-lobated shape of caudal aliform expansion are common between $F$. antillensis and the new species, the procuticular supports of aliform expansions in $F$. antillensis is rudimentary and is much smaller than those in the new species.

The name of the new species is from the Latin glarea (gravel), in reference to the substrata from which this species was discovered.

Diagnosis: Florarctus with spines in legs I-III. The frontal aliform expansion fused with proximal half of the scapus of the internal cirri near its lateral end. The anterolateral and midlateral expansions fused with each other; a fold remaining there. The proximal half of the midlateral and posterolateral expansions fused with each other; the distal half of them overlapping each other. The posterolateral expansion with round central notch. The caudal expansion with a central notch and a pair of side notches. Each expansion, except frontal one, with procuticular supports. Scapus of the lateral cirrus fused with the primary clava. External digit very short, with a hook-shaped peduncle. Internal digit about twice as long as external digit. External claw consisting of a large proximal piece and a small distal one, with a distinct calcar externum. Internal claw smaller than external claw, not separated into pieces as external claw, with an accessory hook, with an indistinct calcar externum.

\section{Acknowledgment}

I wish to express my sincere thanks to Dr. Tatsunori Itô, the Seto Marine Biological Laboratory, who reviewed the manuscript critically.

\section{References}

Delamare Deboutteville, C. \& J. Renaud-Mornant. 1965a. Un remarquable genre de tardigrades des sables coralliens de Nouvelle-Calédonie. G.r. hebd. Seanc. Acad. Sci., Paris, 260: 25812583.

Nouvelle-Calédonie. Cah. Pacif., 9: 1965b. Un nouveau genre

Grimaldi de Zio, S., M. D’Addabbo Gallo, M.R. Morone de Lucia, \& P. Grimaldi. 1980. Ulteriori dati sui tardigradi del mesopsammon di alcune pugliesi. Thalassia Salentina, N.S., 10: 43-65.

- -1980 . Osservazioni sullo sviluppo postembrionale di Florarctus hulingsi Renaud-Mornant (Heterotardigrada). Mem. Biol, Mar. Oceanogr., Suppl., 10: 407.

Kristensen, R.M. 1984. On the biology of Wingstrandarctus corallinus nov. gen. et spec., with notes on the symbiontic bacteria in the subfamily Florarctinae (Arthrotardigrada). Vidensk. Meddr dansk naturh. Foren., 145: 201-218.

Renaud-Mornant, J. 1967. Tardigrades de la Baie Saint-Vincent, Nouvelle-Calédonie. Exp. Fr. Récifs Coral. Nouvelle-Calédonie (edit. Singer-Polignac), 2: 103-119.

1970. Tardigrades marins des Bermudes. Bull. Mus. natn. Hist. nat., Sér. 2, 42: 12681276. 
1976. Le genre Florarctus Delamare Deboutteville et Renaud-Mornant, 1965, en Méditerranée; description de deux espèces nouvelles (Arthrotardigrada). Bull. Mus. natn. Hist. nat., Paris, Sér., 3, 369, Zool. 257: 325-333.

- 1979. Tardigrades marins de Madagascar. I. Halechiniscidae et Batillipedidae. Bull. Mus. natn. Hist. nat., Paris, Sér., 4, l(A) : 257-277.

1982. Sous-famille et genre nouveaux de tardigrades marins (Arthrotardigrada). Bull. Mus. natn. Hist. nat., Paris, Sér., 4, 4(A): $89-94$.

Van der Land, J. 1968. Florarctus antillensis, a new tardigrade from the coral sand of Curaçao. Stud. Fauna Curaçao, 25: 140-146. 